\title{
5-Hydroxytryptamine Evokes Endothelial Nitric Oxide Synthase Activation in Bovine Aortic Endothelial Cell Cultures (44423)
}

\author{
J. Eric Mcduffie, ${ }^{*}, 1$ Sonya D. Coaxum, $\dagger$ and Mohammed A. Maleque $\dagger$ \\ Department of Pathology, * University of Michigan Medical School, Ann Arbor, Michigan 48109; and Department of Pharmacology, $\dagger$ \\ Meharry Medical College, Nashville, Tennessee 37208
}

\begin{abstract}
Activation of endothelial nitric oxide synthase (eNOS) results in the production of nitric oxide (NO) that mediates the vasorelaxing properties of endothelial cells. The goal of this project was to address the possibility that 5-hydroxytryptamine (5-HT) stimulates eNOS activity in bovine aortic endothelial cell (BAEC) cultures. Here, we tested the hypothesis that $5-\mathrm{HT}$ receptors mediate eNOS activation by measuring agonist-stimulated $\left[{ }^{3} \mathrm{H}\right] \mathrm{L}$-citrulline $\left(\left[{ }^{3} \mathrm{H}\right] \mathrm{L}-\mathrm{Cit}\right)$ formation in BAEC cultures. We found that 5 -HT stimulated the conversion of $\left[{ }^{3} \mathrm{H}\right] \mathrm{L}$-arginine $\left(\left[{ }^{3} \mathrm{H}\right] \mathrm{L}-\mathrm{Arg}\right)$ to $\left[{ }^{3} \mathrm{H}\right] \mathrm{L}-\mathrm{Cit}$, indicating eNOS activation. The high affinity $5-\mathrm{HT}_{1 \mathrm{~B}}$ receptor agonist, 5-nonyloxytryptamine (5-NOT)-stimulated $\left[{ }^{3} \mathrm{H}\right] \mathrm{L}-\mathrm{Cit}$ turnover responses were concentration-(0.01 $\mathrm{n} M$ to 100 $\mu M)$ and time-dependent. Maximal responses were observed within $10 \mathrm{~min}$ following agonist exposures. These responses were effectively blocked by the $5-\mathrm{HT}_{1 \mathrm{~B}}$ receptor antagonist, isamoltane, the $5-\mathrm{HT}_{1 \mathrm{~B}} / 5-\mathrm{HT}_{2}$ receptor antagonist, methiothepin, and the eNOS selective antagonists $(0.01-10 \mu M)$ : L- $N^{\omega}$-monomethyl-L-arginine (L-NMMA) and L- ${ }^{\omega}{ }^{\omega}$-iminoethyl-L-ornithine (L-NIO). Pretreatment of BAEC cultures with pertussis toxin (PTX; $1-100 \mathrm{ng} / \mathrm{ml}$ ) for $16 \mathrm{hr}$ resulted in significant inhibition of the agoniststimulated eNOS activity, indicating the involvement of $G_{i}$ proteins. These findings lend evidence of a $5-\mathrm{HT}_{1 \mathrm{~B}}$ receptor/eNOS pathway, accounting in part for the activation of eNOS by 5-HT. Further investigation is needed to determine the role of other vascular 5-HT receptors in the stimulation of eNOS activity. [P.S.E.B.M. 1999, Vol 221]
\end{abstract}

S everal vasoactive substances elicit the release of nitric oxide (NO) from endothelium following activation of the calcium/calmodulin-dependent enzyme endothelial nitric oxide synthase (eNOS) (1), which has been cloned in both cultured and native bovine aortic endothelial cell (BAEC) cultures (2). The diffusion of NO into vascular smooth muscle cells (VSMCs) results in activation of soluble guanylyl cyclase (solGC) and subsequent vasorelaxation (1). 5-Hydroxytryptamine (5-HT) stimulates endothe-

This project was supported by grants: NSF/RIMI 9550699 and NIH T32 HL077809. ${ }^{1}$ To whom requests for reprints should be addressed at University of Michigan Medical School, Department of Pathology, MSRB I Room 7520, Ann Arbor, MI 48109. E-mail: mcdphd@path.med.umich.edu

Received December 3, 1998. [P.S.E.B.M. 1999, Vol 221]

Accepted April 28, 1999.

0037-9727/99/2214-0386\$14.00/0

Copyright (C) 1999 by the Society for Experimental Biology and Medicine

5-HYDROXYTRYPTAMINE AND NITRIC OXIDE lium-dependent relaxation (EDR) of blood vessels by promoting the release of NO $(3,4)$. The 5-HT-induced EDR of blood vessels was first demonstrated in histaminecontracted rings of sheep pulmonary vein (5) and characterized in porcine coronary arteries (6). Using molecular cloning techniques, Ullmer et al. (4) elucidated the expression of mRNAs for the G-protein-coupled 5- $\mathrm{HT}_{1 \mathrm{~B}}, 5-\mathrm{HT}_{2 \mathrm{~B}}$, and $5-\mathrm{HT}_{4}$ receptors in human endothelial cells. However, the underlying mechanisms responsible for 5-HT-evoked eNOS activation have not been fully defined. Inhibition of agonist-stimulated EDR responses by the eNOS selective inhibitor, $\mathrm{N}^{\omega}$-monomethyl-L-arginine (L-NMMA) suggests that $5-\mathrm{HT}_{1}$ and $5-\mathrm{HT}_{2}$ receptors mediate eNOS activation $(3,7)$. However, the blockade of eNOS activation by enzyme-selective antagonists provides indirect evidence that 5-HT receptor-mediated eNOS activation results in the release of NO. The elucidation of the underlying mechanisms responsible for 5-HT-induced EDR responses has been complicated by the similar pharmacology of 5-HT $\mathrm{HB}_{1 \mathrm{~B}}$ (formerly named $\left.5-\mathrm{HT}_{1 \mathrm{D}_{\beta}}\right)$ and $5-\mathrm{HT}_{2 \mathrm{~B}}$ receptors $(4,8,9)$. 5-HT-induced EDR responses are resistant to ketanserin (5- 
$\mathrm{HT}_{2}$ receptor antagonist) pretreatment but are attenuated by methiothepin $\left(5-\mathrm{HT}_{1 \mathrm{~B}} / 5-\mathrm{HT}_{2}\right.$ receptor antagonist) pretreatment (10). 5- $\mathrm{HT}_{2 \mathrm{~B}}$ receptors stimulate the release of calcium from the endoplasmic reticulum (11). Although the activation of eNOS requires calcium $(\approx 75 \mu M)(11,12)$, a link between $5-\mathrm{HT}_{2 \mathrm{~B}}$ receptor-mediated intracellular calcium $\left(\mathrm{Ca}^{2+}{ }_{\mathrm{i}}\right)$ signaling and eNOS activity has not been reported. The $5-\mathrm{HT}_{1 \mathrm{~B}}$ receptor subtype inhibits adenylate cyclase (AC) activity (4). Several reports lend evidence of $5-\mathrm{HT}_{1}$ receptor agonist-stimulated EDR of isolated blood vessels in vitro $(10,13,14)$ and in vivo $(15)$. 5-HT receptormediated EDR is blocked by pertussis toxin (PTX) pretreatment, implying receptor-effector coupling through $\mathrm{G}_{\mathrm{i}}$ proteins (16). Therefore, it may be concluded that the putative $\mathrm{G}_{\mathrm{i}}$-coupled 5-HT $\mathrm{HB}_{1 \mathrm{~B}}$ receptor stimulates EDR (14). High affinity 5 -HT receptor-selective ligands $(17,18)$ may be employed to assess the participation of putative 5-HT receptors in the activation of eNOS, accounting for the biological relevance of $\mathrm{NO}$ and the $\mathrm{G}_{\mathrm{i}}$-coupled $5-\mathrm{HT}_{1 \mathrm{~B}}$ receptor second messenger system.

In the present study, we examined the role of endothelial 5-HT receptors in the activation of eNOS in BAEC cultures. Specifically, we tested whether 5-HT evokes eNOS activation in BAEC cultures by measuring agoniststimulated $\left[{ }^{3} \mathrm{H}\right] \mathrm{L}$-citrulline $\left(\left[{ }^{3} \mathrm{H}\right] \mathrm{L}-\mathrm{Cit}\right)$ formation by radioimmunoassay. Our data clearly indicate that 5-HT and the $5-\mathrm{HT}_{1 \mathrm{~B}}$ receptor agonist, 5-NOT stimulate the conversion of $\left[{ }^{3} \mathrm{H}\right] \mathrm{L}-\mathrm{Cit}$ from $\left[{ }^{3} \mathrm{H}\right] \mathrm{L}$-arginine $\left(\left[{ }^{3} \mathrm{H}\right] \mathrm{L}-\mathrm{Arg}\right)$.

\section{Materials and Methods}

Materials. Dulbecco's Modified Eagle's Medium (DMEM), 5-HT, and pertussis toxin were purchased from Sigma (St. Louis, MO). Cell culture reagents were obtained from Life Technologies (Grand Island, NY). [ $\left.{ }^{3} \mathrm{H}\right] \mathrm{L}$-arginine $(53.0 \mathrm{Ci} / \mathrm{mmol} ; 1 \mathrm{Ci} / \mu \mathrm{l}=37 \mathrm{GBq})$ was purchased from Amersham (Arlington Heights, IL). BCA protein assay kits were purchased from Pierce (Rockford, IL). L-NIO, LNMMA, and calmodulin were obtained from Calbiochem (La Jolla, CA). Isamoltane, methiothepin, and 5-NOT were purchased from Tocris-Cookson (Ballwin, MO).

Cell Culture. Bovine aortic endothelial cells (BAEC) were purchased from Clonetics (San Diego, CA) and cultured according to the supplier's reference protocol. Throughout the duration of study, we used cell cultures from the 6th-15th passages during which the investigative parameters were maintained as described previously by Inoue et al. (19). The cells for all protocols were deprived of serum for $16 \mathrm{hr}$ to achieve quiescence.

eNOS Assay. Measurement of eNOS activity was achieved by using an adaptation of the protocol described previously by Bredt and Snyder (20). For routine assays, BAEC grown on 6 -well plates $\left(3 \times 10^{4}\right.$ cells/well $)$ were washed once with PBS containing $1 \mathrm{~m} M$ EDTA and subsequently stimulated with selected ligands in a mixture (final volume of $0.8 \mathrm{ml})$ containing $\left[{ }^{3} \mathrm{H}\right] \mathrm{L}-\operatorname{Arg}(1 \mu \mathrm{Ci}), 1 \mathrm{mM}$
$\mathrm{CaCl}_{2}, 0.1 \mu M$ calmodulin, $1 \mathrm{~m} M$ DTT, $50 \mathrm{~m} M$ Tris- $\mathrm{HCl}$ (pH 7.4), $100 \mu M \mathrm{BH}_{4}$, and $10 \mathrm{~m} M \mathrm{NADPH}$ prepared in 10 $\mathrm{m} M$ Tris- $\mathrm{HCl}(\mathrm{pH} 7.4)$ for specified durations at $37^{\circ} \mathrm{C}$. Control reactions were chemically inhibited by the addition of $500 \mu M$ L-NIO. Reactions were terminated by rapid aspiration of reaction buffer and the addition of $800 \mu$ l of stop buffer consisting of $50 \mathrm{~m} M$ HEPES ( $\mathrm{pH}$ 5.5), $5 \mathrm{~m} M$ EDTA, and Dowex 50WX8-400 resin ( $\mathrm{Na}^{+}$form). For collection of samples, tissue culture cells were scraped with a rubber policeman and then pipetted into separate microcentrifuge tubes, while on ice. The samples were then transferred to microfuge cups and microcentrifuged at full speed for 30 sec at $4^{\circ} \mathrm{C}$. The spin cups were removed from the cup holders. Eluates were transferred to scintillation vials. Following the addition of scintillation cocktail, radioactivity was quantitated in a liquid scintillation counter. To determine the ratio of unreacted $\left[{ }^{3} \mathrm{H}\right] \mathrm{L}-\mathrm{Arg}$ to $\left[{ }^{3} \mathrm{H}\right] \mathrm{L}-\mathrm{Cit}$, the spin cups were placed in fresh microcentrifuge tubes. Elution buffer consisting of $0.5 \mathrm{M} \mathrm{NH}_{4} \mathrm{Cl}$ was added to each sample tube and subsequently microcentrifuged at full speed for $30 \mathrm{sec}$ at $4^{\circ} \mathrm{C}$. The eluates were transferred to scintillation vials, and radioactivity was quantitated as described above. To verify $\left[{ }^{3} \mathrm{H}\right] \mathrm{L}-\mathrm{Cit}$ formation, $\left[{ }^{3} \mathrm{H}\right] \mathrm{L}-\mathrm{Arg}$ and relevant metabolites were separated using silica-gel chromatography plates developed with the solvent system consisting of methanol:ammonium hydroxide $(6: 1)$. In this solvent system, $\left[{ }^{3} \mathrm{H}\right] \mathrm{L}-\mathrm{Arg}$ migrated at an $R_{\mathrm{f}}$ (the ratio of the distance traveled by a compound to the distance traveled by its solvent) of $\approx 0.1$ whereas $\left[{ }^{3} \mathrm{H}\right] \mathrm{L}$-Cit migrated at an $R_{\mathrm{f}}$ of $\approx 0.5$. Protein concentrations were quantitated using Pierce's BCA protein assay kit.

Statistical Analysis. eNOS assays were performed on triplicate samples. We found these concentration- and time-response courses to be highly reproducible. The pooled data were used for statistical analysis by Student's $t$ test with Jandel program for Windows; $P$-values $<0.0001$.

\section{Results}

Concentration- and Time-Dependent Effects of 5-HT Agonists on eNOS Activity. In our preliminary efforts to assess the role of endothelial 5-HT receptors in the activation of eNOS, BAEC cultures were stimulated with 5 -HT or the 5- $\mathrm{HT}_{1 \mathrm{~B}}$ receptor agonist 5-NOT. Concentration-dependent increases in eNOS activity were observed from 0.001-100 $\mu M$ 5-HT (Fig. 1A). Stimulation of eNOS activity by $1 \mu M$ 5-HT occurred within 5 min of treatment and was maximal by $10 \mathrm{~min}$ after 5-HT exposure (Fig. 1B). The eNOS activity achieved with 5-NOT was concentration- and time-dependent. The activity observed following 5-NOT exposure is qualitatively similar to that achieved with 5-HT. Furthermore, chromatographic analysis revealed that the two ligands stimulate the conversion of $\left[{ }^{3} \mathrm{H}\right] \mathrm{L}-\mathrm{Arg}$ to $\left[{ }^{3} \mathrm{H}\right] \mathrm{L}-\mathrm{Cit}$ (data not shown).

Effects of Isamoltane and Methiothepin on 5-NOT-Stimulated eNOS Activity. The 5-NOT- 
A.

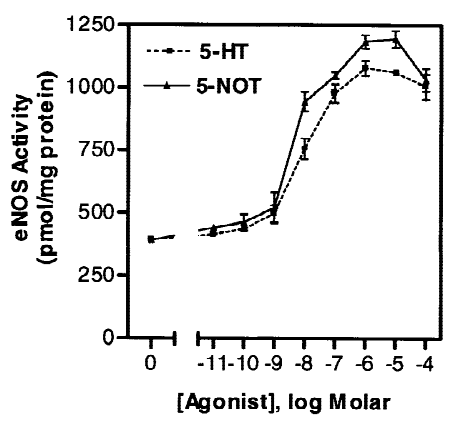

B.

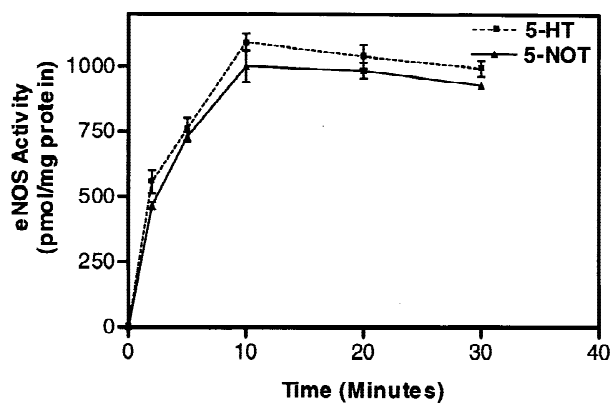

Figure 1. Stimulation of eNOS activity by 5-HT and 5-NOT: BAEC cultures were incubated with the indicated concentrations of $5-\mathrm{HT}$ or 5-NOT for 10 min (Fig. 1A). eNOS activity was measured as described under "Materials and Methods" and expressed as pmol/mg protein, where basal enzyme activity was defined in unstimulated cells as 0 . BAEC cultures were incubated with $1 \mu M$ of 5 -HT or 5 -NOT for the indicated times (Fig. 1B). Values shown represent the mean \pm SE of three separate experiments performed in triplicate.

stimulated eNOS activity (Fig. 2) was effectively blocked by the $5-\mathrm{HT}_{1 \mathrm{~B}}$ receptor-selective antagonist, isamoltane (10 $\mu M)$ and the $5-\mathrm{HT}_{1 \mathrm{~B}} / 5-\mathrm{HT}_{2}$ receptor antagonist, methio-

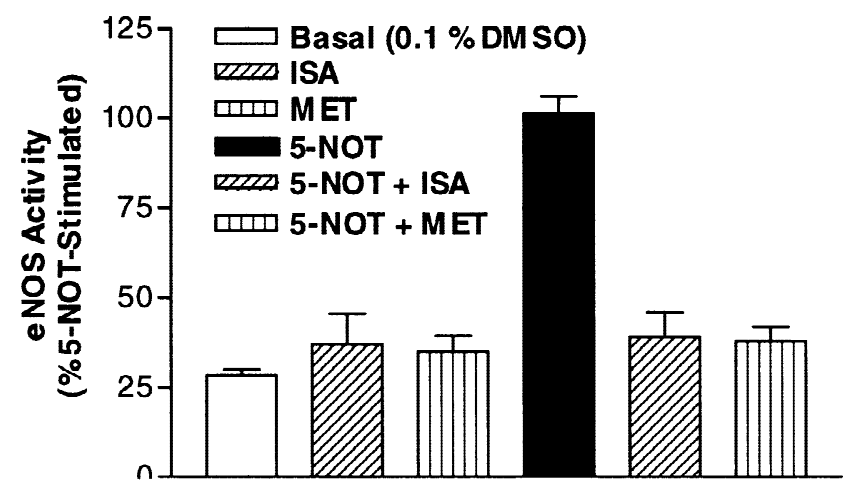

Figure 2. Effects of a 5-HT receptor antagonists isamoltane and methiothepin on 5-NOT-stimulated eNOS activity. BAEC cultures were preincubated for $30 \mathrm{~min}$ with either vehicle $(0.1 \%$ DMSO; basal) or antagonist $(10 \mu \mathrm{M})$ and stimulated with $1 \mu \mathrm{M}$ 5-NOT for 10 min. eNOS activity was measured as described under "Materials and Methods" and expressed as \% 5-NOT-stimulated. Values shown represent the mean \pm SE of three separate experiments performed in triplicate. thepin $(10 \mu M)$. The decrease in eNOS activity, due to isamoltane and methiothepin, indicates that the 5-NOTstimulated activation of eNOS was mediated by specific $5-\mathrm{HT}_{1 \mathrm{~B}}$ receptors.

Inhibition of 5-HT Receptor-Mediated eNOS Activity by L-NMMA and L-NIO. To examine the sensitivity of 5-HT-stimulated eNOS activity to eNOS-directed antagonists, BAEC cultures were preincubated $(30 \mathrm{~min})$ with eNOS selective inhibitors (0.01-10 $\mu M$ ) L-NMMA (Fig. 3A) and L-NIO (Fig. 3B). The 5-HT- and 5-NOTstimulated activity was inhibited following L-NMMA and L-NIO pretreatment.

Blockade of 5-HT Receptor-Mediated eNOS Activity by Pertussis Toxin. As shown in Figure 4, subconfluent quiescent BAEC cultures were pretreated for 16 hr with pertussis toxin (PTX; 1-100 ng/ml) and stimulated with 5-HT and 5-NOT. The PTX pretreatment abolished eNOS activity following agonist exposure. These data suggest that 5-HT transmits its signals through PTX-sensitive $5-\mathrm{HT}_{1 \mathrm{~B}}$ receptors, leading to the activation of eNOS.

A.

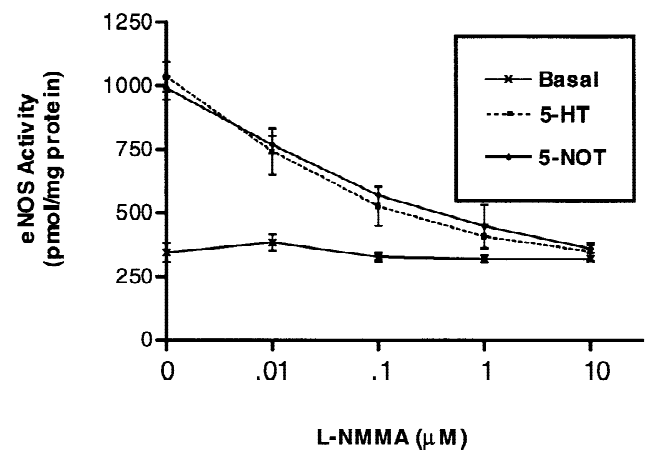

B.

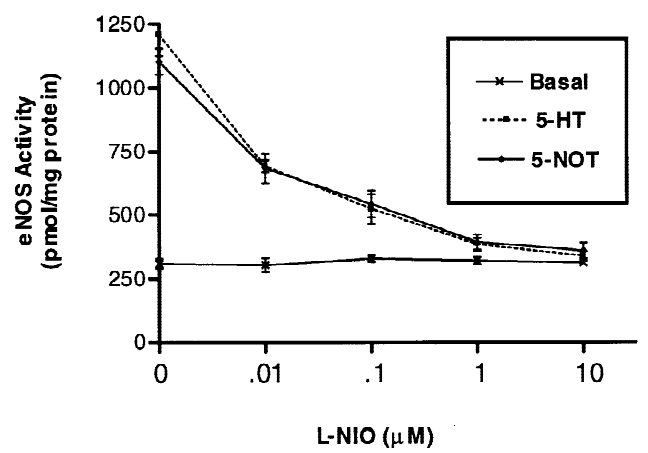

Figure 3. Effects of eNOS antagonists L-NMMA (Fig. 3A) and L-NIO (Fig. 3B) on 5-HT- and 5-NOT-stimulated eNOS activity. BAEC cultures were preincubated for 30 min with either vehicle $(0.1 \%$ DMSO; basal), L-NMMA or L-NIO at the specified concentrations and stimulated with $1 \mu M 5-\mathrm{HT}$ or 5 -NOT for 10 min. eNOS activity was measured as described under "Materials and Methods" and expressed as $\mathrm{pmol} / \mathrm{mg}$ protein. Values shown represent the mean \pm SE of three separate experiments performed in triplicate. 


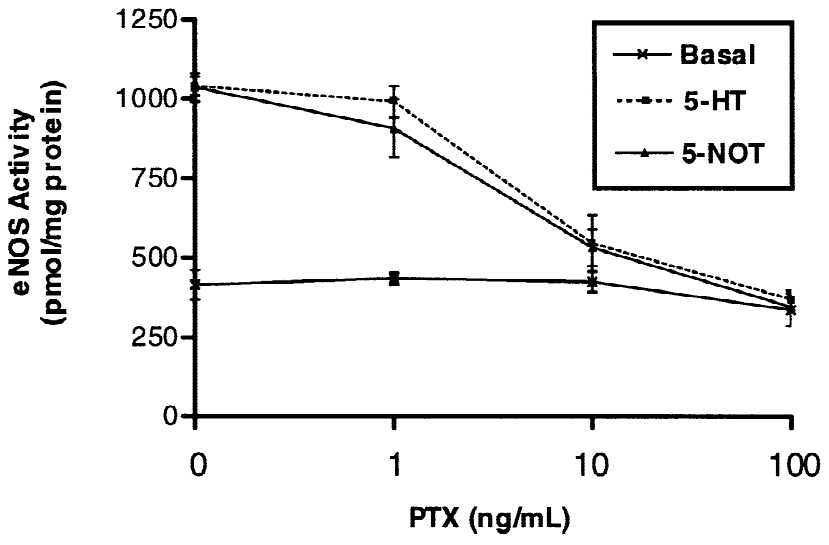

Figure 4. Effect of $\mathrm{G}_{\mathrm{i}}$ protein inhibitor pertussis toxin (PTX) on 5-HTand 5-NOT-stimulated eNOS activity. BAEC cultures were preincubated for $16 \mathrm{hr}$ with either vehicle $(0.1 \%$ DMSO; basal) or PTX at the specified concentrations and stimulated with $1 \mu M 5-\mathrm{HT}$ or 5 -NOT for 10 min. eNOS activity was measured as described under "Materials and Methods" and expressed as pmol/mg protein. Values shown represent the mean \pm SE of three or more separate experiments performed in triplicate.

\section{Discussion}

The signaling mechanism leading to the activation of eNOS and subsequent release of NO by endothelial 5-HT receptors has not been clearly defined. The release of NO and the EDR response mediated by 5-HT receptors may occur through different pathways involving $\mathrm{G}_{\mathrm{i}}$-proteindependent and independent mechanisms (3-7). Signal transduction through the 5- $\mathrm{HT}_{1 \mathrm{~A}}$ receptor in minced rat ventral prostatic tissue appears to be negatively coupled to $\mathrm{AC}$ activity and positively coupled to nitric oxide synthase (21). At present, there are no data that suggest the presence of $5-\mathrm{HT}_{1 \mathrm{~A}}$ receptors in endothelial cells (4). The serotonergic receptors expressed in endothelial cells include: the 5- $\mathrm{HT}_{1 \mathrm{~B}}$, $5-\mathrm{HT}_{2 \mathrm{~B}}$, and $5-\mathrm{HT}_{4}$ receptor subtypes (4). The $5-\mathrm{HT}_{4}$ receptor has not been implicated in the activation of eNOS by 5-HT; however, the positive coupling of these receptors to AC (9) renders it capable of counteracting the effects of $5-\mathrm{HT}_{1 \mathrm{~B}}$ receptors that interact positively with $\mathrm{AC}$ in endothelium (4). As reviewed by Martin (9), several reports suggest that vascular 5- $\mathrm{HT}_{2 \mathrm{~B}}$ receptors function to mediate activation of phospholipase $\mathrm{C}$ (PLC) via $\mathrm{G}_{\mathrm{q}}$ proteins. Current literature suggests that $5-\mathrm{HT}_{2 \mathrm{~B}}$ receptors may play a role in the activation of eNOS (4), yet there are no reports to date that state evidence justifying such function of $5-\mathrm{HT}_{2 \mathrm{~B}}$ receptors. While 5- $\mathrm{HT}_{1 \mathrm{~B}}$ and $5-\mathrm{HT}_{2 \mathrm{~B}}$ receptors share a similar pharmacology (8), the 5- $\mathrm{HT}_{2 \mathrm{~B}}$ receptor agonist, 1-(2,5dimethoxy-4-iodopheny)-2-aminopropane (DOI) stimulates $\mathrm{Ca}^{2+}{ }_{\mathrm{i}}$ release from ryanodine-sensitive stores in endothelial cells, a function that occurs independent of 5- $\mathrm{HT}_{1 \mathrm{~B}}$ receptors (11). The ability of DOI to elicit changes in $\mathrm{Ca}^{2+}{ }_{i}$ transients independent of $5-\mathrm{HT}_{1 \mathrm{~B}}$ receptor activation in endothelial cells, further suggests two different signal transduction pathways for the two receptors and perhaps different roles as they relate to 5-HT-stimulated vascular function(s). Furthermore, the distinct transducer pathway for the
5- $\mathrm{HT}_{1 \mathrm{~B}}$ receptors in endothelium has not been identified (9). The characterization of $\left[{ }^{3} \mathrm{H}\right] \mathrm{L}-\mathrm{C}$ it formation responses evoked by 5 -HT receptors in BAEC cultures, suggests a stimulatory role of 5- $\mathrm{HT}_{1 \mathrm{~B}}$ receptors (22).

In the present study, control experiments using 5-HT and the 5- $\mathrm{HT}_{1 \mathrm{~B}}$ receptor selective agonist, 5-NOT demonstrated concentration- and time-dependent agonist-evoked changes in eNOS activity (Fig. 1). Maximum activity was reached at $10 \mathrm{~min}$ following agonist exposure. The $5-\mathrm{HT}_{1 \mathrm{~B}}$ receptor antagonist, isamoltane, and the $5-\mathrm{HT}_{1 \mathrm{~B}} / 5-\mathrm{HT}_{2} \mathrm{re}-$ ceptor antagonist, methiothepin, effectively blocked eNOS activity evoked by 5-NOT (Fig. 2). Gupta (10) reported that the 5-HT-induced EDR response is not inhibited by the potent $5-\mathrm{HT}_{2 \mathrm{~B}}$ receptor antagonist, ketanserin, but is attenuated by the $5-\mathrm{HT}_{2}$ receptor inhibitor, methiothepin, which is also active as a potent $5-\mathrm{HT}_{1 \mathrm{~B}}$ antagonist. Although it was not the objective of our study to establish a pharmacological link between 5- $\mathrm{HT}_{1 \mathrm{~B}}$ and $5-\mathrm{HT}_{2 \mathrm{~B}}$ receptors, the observed inhibition of agonist-stimulated activation of eNOS by methiothepin is in good agreement with a wellaccepted observation that the two receptors share a similar pharmacology.

As mentioned before, 5-HT-induced EDR responses are resistant to ketanserin $\left(5-\mathrm{HT}_{2}\right.$ antagonist) pretreatment but are effectively inhibited by methiothepin $\left(5-\mathrm{HT}_{1 \mathrm{~B}} / 5-\right.$ $\mathrm{HT}_{2}$ antagonist) pretreatment (10), implicating $5-\mathrm{HT}_{1 \mathrm{~B}}$ but not $5-\mathrm{HT}_{2 \mathrm{~B}}$ receptors in this process. Furthermore, 5-HTstimulated EDR responses are attenuated by inhibitors of NOS (i.e., L-NMMA) (7, 15). We found that the eNOS selective inhibitors (L-NMMA and L-NIO) suppressed both the 5-HT- and 5-NOT-stimulated eNOS activity (Fig. 3). These findings lend evidence of a link between endothelial $5-\mathrm{HT}_{1 \mathrm{~B}}$ receptors and eNOS activity in our BAEC cultures (7).

Several endothelial agonists stimulate eNOS activity that may be ablated by the $\mathrm{G}_{\mathrm{i}}$ protein inhibitor, PTX (14, 16). In addition, we demonstrated that PTX pretreatment abolishes eNOS activation following 5-HT and 5-NOT exposure (Fig. 4). This suggests that the endothelial 5- $\mathrm{HT}_{1 \mathrm{~B}}$ receptors mediate eNOS activity via a $\mathrm{G}_{\mathrm{i}}$ protein coupling mechanism.

The current studies demonstrate for the first time that the activation of eNOS is stimulated by PTX-sensitive $5-\mathrm{HT}_{1 \mathrm{~B}}$ receptors in BAEC cultures. In conclusion, these data suggest that $5-\mathrm{HT}$ and $5-\mathrm{HT}_{1 \mathrm{~B}}$ agonists can evoke eNOS activation and the subsequent release of NO from endothelial cells, accounting in part for the EDR of blood vessels.

We thank Evangeline D. Motley, Ph.D., and Lee E. Limbird, Ph.D., for their review of the manuscript prior to publication and Edward Yun for his technical assistance.

1. Cooke JP, Dzua VJ. Nitric oxide synthase: Role in the genesis of vascular disease. Annu Rev Med 48:489-509, 1997. 
2. Pollock JS, Forestermann U, Mitchell JA, Warner TD, Schmidt HH, Nakane M, Murad F. Purification and characterization of particulate endothelium-derived relaxing factor synthase from cultures and native bovine aortic endothelial cells. Proc Natl Acad Sci U S A 88:1048010484, 1991.

3. Whiting MV, Cambridge D. Canine renovascular responses to sumatriptan and 5-carboxytryptamine: Modulation through endothelial 5- $\mathrm{HT}_{1}$-like receptors by endogenous nitric oxide. Br J Pharmacol 114:969-974, 1995.

4. Ullmer C, Schmuck K, Kalkman H, Lubbert H. Expression of serotonin receptor mRNA in blood vessels. FEBS Lett 370:215-221, 1995.

5. Eyre P. Atypical tryptamine receptors in sheep pulmonary vein. Br J Pharmacol 55:329-333, 1975.

6. Cocks TM, Angus JA. Endothelium-dependent relaxation of coronary arteries by noradrenaline and serotonin. Nature 305:627-630, 1983

7. Martin GR, Bolofo M-L, Giles H. Inhibition of endotheliumdependent vasorelaxation by arginine analogues: A pharmacological analysis of agonist and tissue dependence. Br J Pharmacol 105:643652, 1992.

8. Choi D, Birraux G, Launay J, Maroteaux L. The human serotonin 5-HT2B receptor: Pharmacological link between 5-HT2 and 5-HT1D receptors. FEBS Lett 352:392-399, 1994.

9. Martin G. Vascular receptors for 5-hydroxytrypatamine: Distribution, function and classification. Pharmacol Ther 62:283-324, 1994.

10. Gupta P. An endothelial 5-HT receptor that mediates relaxation in guinea-pig jugular vein resembles the 5- $\mathrm{HT}_{1 \mathrm{D}}$ subtype. Br J Pharmacol 106:703-709, 1992.

11. Ullmer C, Boddeke HG, Schmuck K, Lubbert H. 5-HT $\mathrm{H}_{2 \mathrm{~B}}$ receptormediated calcium release from ryanodine-sensitive intracellular stores in human pulmonary artery endothelial cells. Br J Pharmacol 117:1081-1088, 1996.

12. Knowles RG, Moncada S. Nitric oxide synthases in mammals. Biochem J 298:249-258, 1994.

13. Molderings GJ, Göthert M, Fink K, Roth E, Schlicker E. Inhibition of noradrenaline release in the pig coronary artery via a novel serotonin receptor. Eur J Pharmacol 164:213-222, 1989.

14. Schoeffter P, Hoyer D. 5-hydroxytryptamine (5-HT)-induced endothelium-dependent relaxation of pig coronary arteries is mediated by 5-HT receptors similar to the 5-HT 1 receptor subtype. J Pharmacol Exp Ther 252:387-395, 1990.

15. Cambridge D, Whiting MV, Butterfield LJ, Marston C. Vascular 5-HT $\mathrm{H}_{1}$-like receptors mediating vasoconstriction and vasodilation: Their characterization and distribution in the intact canine cardiovascular system. Br J Pharmacol 114:961-968, 1995.

16. Flavahan N, Shimokawa H, Vanhouette P. Pertusssis toxin inihibits endothelium-dependent relaxations to certain agonists in porcine coronary arteries. J Physiol 408:549-560, 1989.

17. Glennon RA, Hong SS, Dukat M, Teitler M, Davis K. 5-(Nonyloxy) tryptamine: A novel high-affinity 5-HT1D $\beta$ serotonin receptor agonist. J Med Chem 37:2828-2830, 1994.

18. Sevick J, Ruzicka V, Slansky J, Masek K. Which type of 5-hydroxytryptamine receptor mediates relaxation of the longitudinal muscle of guinea pig proximal colon in vitro? Meth Find Exp Clin Pharmacol 18:421-430, 1996.

19. Inoue N, Hirata K, Yamada M, Hamamori Y, Matsuda Y, Akita H, Yokoyama M. Lysophosphatidylcholine inhibits bradykinin-induced phosphoinositide hydrolysis and calcium transients in cultured bovine aortic endothelial cells. Circ Res 71:1410-1421, 1992.

20. Bredt DS, Snyder S. Isolation of nitric oxide synthase, a calmodulinrequiring enzyme. Proc Natl Acad Sci U S A 87:682-685, 1990.

21. Carmena MJ, Camacho A, Solano RM, Montalvo L, Garcia-Lopez A, Arias A, Prieto JC. 5-hydroxytryptamine1A receptor-mediated effects on adenylate cyclase and nitric oxide synthase activities in rat ventral prostate. Cell Signal 10:583-587, 1998.

22. McDuffie JE, Maleque MA. Evidence of 5-Hydroxytryptamine ${ }_{1 \mathrm{D}_{\beta}}$ (5$\mathrm{HT}_{1 \mathrm{D}_{\beta}}$ ) receptor-mediated activation of endothelial nitric oxide synthase. Pharmacologist 39:19, 1998. 